\title{
M'NAGHTEN AND THE WITCH-DOCTOR: PSYCHIATRY AND CRIME IN AFRICA *
}

\section{ALAN MUINER $\dagger$}

It is easy to understand why psychiatry was a relative latecomer to the medical scene in sub-Saharan Africa. The emphasis of colonial medical services was naturally and properly on providing the qualified personnel and facilities to fight tropical disease, reduce needless mortality and increase life expectancy. For many decades now, resources have been expended on basic remedial work, so much so, in fact, that even adequate preventative programs have had to await the prior provision of doctors, hospitals, nurses and medical supplies; public health specialists are still in short supply. And if the sheer size of the problems - in terms of the numbers of patients, the difficulties of travel and the diversity of language-were not enough, they have been multiplied by the resistance to change produced by superstition and ignorance. ${ }^{1}$

It must be remembered that throughout the colonial period even in Europe psychiatry was only slowly feeling its way forward toward acceptance. Basic ideas of the discipline were still evolving; facilities and personnel were only gradually becoming available as the barriers of European superstition and ignorance began to break down. With psychiatrists in short supply in Europe, few could be made available for service in the colonies. In addition, there was a tendency-sometimes articulated but often not-toward assuming that mental disorder was more the problem of the economically advanced, urbanized and overtly stressful nations. By contrast, the life situation of the less "inhibited" African was seen as not so fraught with possibilities of disturbance. Only the manifestly deranged needed isolation when they created a public nuisance; for the rest, the extended family was frequently seen to act as a general social welfare agency.

* This is a modified version of a chapter of African Penal Systems (Milner ed.), to be published by Routledge \& Kegan Paul (London) in 1967.

† LL.B., LL.M., Ph.D., of Gray's Inn, Barrister-at-Law. Fellow of Trinity College, Oxford. Bicentennial Fellow in Criminal Law and its Administration, University of Pennsylvania, 1965-66. Formerly Professor of Law and Dean of the Faculty of Law, Ahmadu Bello University, Zaria, Northern Nigeria.

1 For a modern synopsis of problems and progress, see 2 KTMBLE, Troprcal AFRICA 159-82 (1960). It must be remembered, of course, that not all superstition impeded the development of modern medical facilities. See, e.g., Ajose, Prevertive Medicine and Superstition in Nigeria, 27 AFr. 268 (1957). 


\section{Modern Psychiatry in Africa}

In consequence, the psychiatric facilities of Africa today are not impressive. A survey south of the Sahara (excluding the Republic of South Africa ${ }^{2}$ ) in $1963^{3}$ revealed that some countries, such as Bechuanaland, Swaziland and the Gambia, had no psychiatrists at all. Cameroun, Gabon, Guinea, Congo (Brazzaville), the Niger Republic and Sierra Leone each had one psychiatrist, but they were not indigenous. Zambia and Tanzania each had two expatriate psychiatrists; Kenya had three expatriates. Senegal had one indigenous and three expatriates; Nigeria had the largest number-ten, only three of whom were from overseas. ${ }^{4}$

Realization of the lack of trained personnel is crucial to the understanding of the problems facing psychiatry in Africa. As with the general practitioner, the scale of the problems confronting the psychiatrist as the tropical countries of Africa began to be developed was such that his time was wholly taken up with his clinical and administrative work. The systematization of the basic groundwork of knowledge therefore suffered so that crucial basic work was perforce neglected. To this day, satisfactory studies of most areas of normal psychology are lacking; the impact of nursing, weaning and later child-rearing practices on developmental psychology is largely unexplored $;^{5}$ and the entire family situation in polygamous and masculinedominated communities remains unexamined by comprehensive study as a factor in personality development.

The psychotherapeutic effectiveness of traditional measures taken by native healers has still to be properly assessed. Mental illnesses are often recognized as such in the customary African community and variously treated by the local equivalents of suggestions, manipulation of the environment, abreaction and group therapy. ${ }^{6}$ The recognition

2 In South Africa there are 12 mental hospitals and 80 psychiatrists. The facilities are available at the rates of 3 beds per 1000 whites and 1 bed per 1000 non-whites. All the psychiatrists are white. See Walton, Psychiatric Practice in a Multiracial Society, 3 Comp. Psycr. 255 (1962).

3 I am indebted to Dr. Tolani Asuni of Aro Hospital, Abeokuta, Nigeria, for this information and for his helpful comments on this section of the article.

4 The division into indigenous and expatriate is not fanciful. Quite apart from problems of language, it may well be that social stresses in any given culture may make interracial communication more difficult in the doctor-patient relationship. See, e.g., Walton, supra note 2. Dawson, Urbanization and Mental Health in a West African Community, in Magrc, FaITH aNd Healing 305 (Kiev ed. 1965), reports that in Sierra Ieone patients are often removed from the mental hospital and taken to traditional healers "that have complete understanding of the social complications involved."

5 But see Albino \& Thompson, The Effects of Sudden Weaning on Zulu Children, 29 BRIT. J. MED. PsycH. 177 (1956).

6 These are dealt with in detail in the Yoruba context in Prince, Indigenous Yoruba Psychiatry, in MAGIC, FAITH aNd Healing, op. cit. supra note 4, at 84 . See 
and use of these culturally oriented agencies as part of the mental health programs of developing countries in Africa has actually taken place in Nigeria ${ }^{7}$ and has been urged elsewhere. ${ }^{8}$ But whatever empirical studies have been undertaken, it is too extravagant to say, as one commentator has, that the traditional measures "are as effective and as scientifically sound as any . . . practised in Europe." 9

Against this background of lack of scientific information, it is easy for the transient observer to give a generalized and wholly misleading-often an unfortunately ethnocentrically prejudiced-picture of African psychology and psychiatry. It is not many years ago, for example, that the psychiatric world was reliably informed that "normal African mentality closely resembles the mentality of a section of the European population which is entitled psychopathic or sociopathic," and that "for the most part Bantu Africans are very happy-go-lucky and inaggressive and would fall into the category of psychopaths called 'inadequate." "10 By the same token, incidence studies, both in general terms and in relation to specific psychiatric categories, have been shallow and misleading. Depressive illnesses have been said to be rare, neurotic conditions seldom encountered and psychosomatic disorders typically non-African.

It is now clear that many of these misconceptions about African mental illness are the result of too hasty a survey of the local scene and too uncritical an application of psychiatric concepts across cultural boundaries. Psychiatric workers now accept that

Both anthropologists and psychiatrists face the astonishingly difficult task of evaluating behavior in terms of a series of factors, including its relation to accepted norms of behavior for a given culture and the adequacy of behavior in its social setting. A principal danger comes from mistaking the

also Fiedd, The SEARCH FOR SECURTTY passim (1960); Gelfand, Psychiatric Disorders as Recognized by the Shona, in Magic, FAITH AND Healing, op. cit. supra note 4, at 156; Messing, Group Therapy and Social Status in the Zar Cult of Ethiopia, in Culture and Mental Healte 319 (Opler ed. 1959); An Ndembu Doctor in Practice, in Magic, FaIte and Healing, op. cit. supra note 4, at 230.

7 See Lambo, Neuropsychiatric Observations in the Western Region of Nigeria, 1956 BRIT. MED. J. 1388; Lambo, Patterns of Psychiatric Care in Developing African Countries, in MAGIC, FAITH AND HEALING, op. cit. supra note 4, at 443, 447-51; Randal, Witch Doctors and Psychiatry, Harpers, Dec. 1965, p. 56.

8 Jahoda, Traditional Healers and Other Institutions Concerned With Mental Illness in Ghana, 7 INT'L J. Soc. PsycH. 245 (1961). The integration proposal is contained in most of the contributions to MAGIC, FAITH AND HEALING, op. cit. supra note 4. Opposition to integration appears to be based on a rigid commitment to Western psychiatry and an over-simplification of the problem of supply and demand in Africa. See Margetts, The Future of Psychiatry in East Africa, $37 \mathrm{E}$. AFr. MED. J. 448 (1960).

9 Iambo, supra note 7, at 1389.

10 Carothers, Frontal Lobe Function of the African, 97 J. Ment. Scr. 112 (1951). 
culturally defined norms of behavior in Western culture to be ideal standards. ${ }^{11}$

The recognition of symptoms and the diagnosis of illness will therefore depend not only upon the psychiatrist's ability to overcome the language barrier but even more so on his ability to understand the cultural background in which he is working. The interpretation of behavior or the identification of delusions, for instance, will be impossible unless he has some familiarity with cultural norms and is able to take them into proper account when reaching his conclusions. Such matters as local peculiarities of family patterns, cultural conceptions of causation ${ }^{12}$ and the widespread but varying beliefs in the immediate physical and mental consequences of supernatural action, will form an essential background to the understanding of abnormality. And even then, a psychiatrist working within a culture which is his own may experience difficulty in delineating confidently where normal cultural beliefs cease and mental illness begins. ${ }^{13}$

With caution, however, one may say that the patterns of psychiatric disorder among Africans are closely akin to the known patterns already familiar in Euro-American cultures. There are, of course, demonstrated qualitative differences, but, despite doubts which have been expressed, ${ }^{14}$ it seems that in most cases these are susceptible to interpretation within the framework of the socio-cultural setting. Schizophrenia, for instance, particularly in its simple and hebephrenic forms, is commonly reported as the most prevalent psychosis. ${ }^{15}$ Episodic confusion and hysteria-like symptoms characterize the illness to a greater extent than in Europe and, although the manic picture is easily recognized by its exhilaration of mood and thought, the depressive syndrome is less frequently manifested and more difficult to

11 Wittkower \& Fried, The Problems of Transcultural Psychiatry, in CuLruRE aNd Mental. Health, op. cit. supra note 6, at 492. Cf. Leighton, Lanso \& OtHers, Psychiatric Disorder Among the Yoruba (1963) (see especially ch. VI, "The Problem of Cultural Distinction").

12 In particular, idea systems which rely heavily on belief in supernatural causation have profound implications for analysis, diagnosis and treatment. LEIGHTON, LANBB \& OTHERS, op. cit. supra note 11 , at 113-14, report that the Yoruba ascribe causative power in mental illness to such factors as malignant influences-superhuman and human, drugs and medicines, heredity, contagion, fate, violation of one's own destiny, cosmic forces and physical or psychological traumata.

13 E.g., Lambo, The Role of Cultural Factors in Paranoid Psychosis Among the Yoruba Tribe, $101 \mathrm{~J}$. MENT. ScI. 239, 247 (1955) (speaking of the differentiation between normal cultural beliefs in supernatural powers and paranoid psychosis).

14 See, e.g., Tooth, Studies in Mental Illness in the Gold Coast 41 (1950).

15 See Carothers, The African Mind in Health and Disease 139 (1955), and studies cited therein; Benedict \& Jacke, Mental Illness in Primitive Societies, 17 Psyc日. 377 (1954); Lambo, Further Neuropsychiatric Observations in Nigeria, 1960 BRIT. MED. J. 1696-97 (noting no predominance of any subvariety); Loudon, Psychogenic Disorder and Social Conflict Among the Zulu, in CULTURe AND MENTal HEALTH, op. cit. supra note 6, at 363; Walton, supra note 2 , at 262. 
identify by mood criteria alone. Organically-based or predisposed conditions are regularly found, associated with trypanosomiasis, malaria, venereal infection and nutritional deficiencies. ${ }^{16}$ It has generally been found that neurotic conditions are more likely to take culturally tolerable forms in African contexts and therefore less frequently find their way to mental hospitals. ${ }^{17}$ It is equally clear, nonetheless, that strong cultural emphasis on sexual potency in the male and fertility in the female and intensive belief in witchcraft and supernatural powers are powerful anxiety-inducing agents. As the scope of psychiatric investigation has widened to surveying hospital out-patients, as well as those attending native healers and shrines, a greater range of neurosis has been disclosed. ${ }^{18}$ In the whole range of clinical reports from African countries, only one distinctively African syndrome has been noted which it is claimed cannot be understood in terms of traditional diagnostic categories; and it is still uncertain how far this can be regarded as a separate disease entity. ${ }^{19}$

It is important to stress again that it is only with the more careful modern studies that the above picture of the incidence of African mental illness has been built up. Past studies had concentrated their attention too narrowly on mental institutions. In developed countries this would be misleading enough; in Africa it proved to be infinitely worse. The solitary mental hospitals have all too often become havens for "criminal lunatics, homicidal lunatics and lunatics without known domicile," as one older study expressed it, ${ }^{20}$ and even today one of their primary functions is not so much the treatment of the ill as the protection of the public from the dangerous. ${ }^{21}$ With the present differential in cultural development within African countries, it has become clear as well that urban areas present atypical samples of mental

16 CARothers, op. cit. supra note 15, ch. 9; Loudon, supra note 15 , at 363 ; Wittkower \& Fried, supra note 11, at 493.

17 CAROTHERS, op. cit. supra note 15, at 148-52; Loudon, supra note 15, at 364-65.

18 Lambo, supra note 15, at 1700-02 (out-patients and patients at native treatment centers); Walton, supra note 2 , at 262 (out-patients). FIELD, op. cit. supra note 6 , at 149 , reported that depression was the most common mental illness encountered among rural Akan (Ghana) women "and nearly all such patients come to the shrines with spontaneous self-accusations of witchcraft."

19 See Lambo, Malignant Anxiety: A Syndrome Associated With Criminal Conduct in Africans, $108 \mathrm{~J}$. MENT. Scr. 256 (1962). One suspects that like the "frenzied anxiety" reported by CAROTHERS, op. cit. supra note 15, Lambo's "malignant anxiety" is only of pathoplastic significance in schizophrenia and not a disease sui generis.

20 See Shelley \& Watson, An Investigation Concerning $M$ ental Disorder in the Nyasaland Native, 82 J. MENT. Scr. 701, 703 (1936) (a study of the Central Lunatic Asylum, Zomba, Nyasaland (now Malawi)).

21 Cf. Tootr, op. cit. supra note 14, at 24 (discussing the Colonial Mental Hospital, Accra, Gold Coast (now Ghana)) ; Dawson, supra note 4 (discussing. Kissy Mental Hospital, Sierra Leone). It is interesting to note that in South Africa, where the psychiatric facilities for non-whites are limited, see note 2 supra, the rate of admission of non-whites to mental hospitals following criminal charges is extremely high. The remaining non-white admissions were all classified as emergencies. See Walton, supra note 2 , especially Table 2 . 
illness. As Field reported following her work in rural areas of Southern Ghana:

A depressed patient is not considered mentally ill, for she is correctly orientated, accessible, and says nothing which isin the ideological setting-irrational. . . . The depressive personality is, in sickness and health, self-effacing and is seldom a disturbing nuisance. She is therefore the last type of patient who would ever find her way to any kind of European hospital unless she had some concurrent and conspicuous trouble. . . . It is not surprising therefore that psychiatrists and other doctors who see patients only in hospitals and clinics should have the idea that depression in Africans hardly exists. ${ }^{22}$

Potentially one of the most powerful forces affecting the incidence of mental illness in African countries today is the rapid rate of cultural change. It has long been pointed out that

mental health problems grow in direct relation to the disturbing of traditional bonds that hold families and communities together. It is suggested that individuals socialized under such well-knit family conditions may suffer when they are estranged from traditional systems of security arrangements previously rooted in the family. ${ }^{23}$

It is only fair to say that much of the evidence to support this statement is of necessity highly impressionistic. Few field workers have been able to deal with the problem in depth with adequate clinical and psychological facilities or with precise controls.

Tooth was able to discern in Ghana no apparent statistical relationship between psychosis and Europeanization, taking literacy as the criterion of the latter. ${ }^{24}$ Carothers' inquiries were no more conclusive. ${ }^{25}$ Lambo observed that both the prevalence and symptom pattern of disorders differed as between literate and nonliterate groups. ${ }^{28}$ In Algeria, DeVos and Miner reported evidence from Rorschach protocols that "attenuation of traditional beliefs in the urbanized Arab is related to increasing intro-psychic tensions," though by adhering to traditional social and religious beliefs they were not forced into patterns of dramatic cultural adaptation. ${ }^{27}$

22 FIELd, op. cit. supra note 6, at 149.

23 Wittkower \& Fried, supra note 11, at 495.

24 Tоoтв, op. cit. supra note 14, at 61-62. He also noted, however, that delusional content in psychosis was determined by cultural factors and that the content in the cases of literate psychotics therefore differed from that of the illiterate. Id. at 52 .

Cf. Wittkower \& Fried, supra note 11.

25 CAROTHERS, op. cit. supra note 15, at 130-33.

28 Lambo, sipra note 13 , at 247.

27 DeVos \& Miner, Oasis and Casbah-A Study in Acculturative Stress, in CuLTURE AND MENTAL HEALTH, op. cit. supra note 6 , at 345 . 
The most significant study in this area is that undertaken by the Cornell-Aro Mental Health Research Project in Western Nigeria. ${ }^{28}$ Based on a primary group of twenty-five villages in the same area and eight parts of a town, it was possible to obtain an appreciable range with regard to size of community, traditional patterns, modernization and degree of socio-cultural integration. Taking such factors as poverty, ineffective leadership, broken homes and breakdown in lineage solidarity as indicative of community disintegration, it was discovered that one and a half times as many people in the disintegrated villages as in integrated places $(22 \%: 14 \%)$ were potential psychiatric "cases." Less than half as many (18\%. :42\%) were "well." The relationship was particularly pronounced for women. In the integrated places there were ten times as many rated "well" as were rated "cases" $(60 \%: 6 \%)$, while in the disintegrated villages there were one and a half times as many women who were "cases" as were "well" $(26 \%: 15 \%)$. Socio-cultural disintegration certainly appears from this study to be directly associated with psychiatric disorder, though is was not indicated whether it preceded or followed it. The assumption must be the latter. At the same time, the role and effects of simple cultural change remain unexplored in detail, though it may perhaps be assumed with some confidence that the rapid cultural changes being experienced in the economic and political development of modern Africa will continue to bring socio-cultural disintegration in their train and thereby predispose to psychiatric disorder those who are enveloped in the changes.

\section{Psychiatry and the Penal System}

Very few African penal institutions, if any at all, are fortunate enough to have full-time medical officers, as basic medical facilities are so poor in the general community. It can easily be assumed that the psychiatric situation is much worse. Although there is good reason for supposing that a greater proportion of deviant and defective personalities will be found in the prison community than in the population at large, there are hardly any specialized prison psychiatric services in the continent.

The absence of these facilities, coupled with the usual lack of development of the general psychiatric facilities in any given community, has two important consequences. First, the residential treatment facilities which generally are available in the communitybe they in the form of a mental hospital (normally only one) or asylums (normally several)-will be undifferentiating in their reception of

28 Published as Leighton, Lambo \& OTHERs, op. cit. supra note 11. 
patients. Civil committals, both voluntary and on certification, will be accommodated side by side with criminal committals, and the less seriously disturbed together with the chronically or acutely disturbed. The same strict security measures will be taken in respect of all patients, and each will receive as much, or as little, treatment as any other, irrespective of his condition. Occasionally, some countries do not allow the mixing of civil and criminal patients, applying security measures only to the criminal classification; they may be kept in individual cells or a few in a cell, as in Gabon, or isolated on an island, as on Fotoba Island in the Republic of Guinea.

Secondly, even though facilities may be labelled "criminal" and "non-criminal," such is the general lack of development of both that the distinction may not easily be recognized. Given that the capacity of properly equipped mental hospitals, where they exist, is strictly limited, the criminal defendant who is found to be irresponsible or unfit to stand trial may find himself committed either to prison or to an asylum physically adjacent to and under common supervision with it. $^{29}$ Once there, occasional sedation may be the extent of the treatment received, and sometimes even this may be more than can be expected. Enahoro's grisly picture of the conditions of "lunatics" in prison in Nigeria twenty years ago may not be far from the truth in many parts of Africa today:

I saw more brutality to those unfortunate wretches in one year than I have seen in all the rest of my life. Considered fair game for baton practice by any warder, they slept on bare floors, often denied blankets, their meals were irregular, they were frequently refused buckets for their natural needs, and some of them might never step out of their cells for weeks. . . . No one seemed to care, except on the rare occasions of the Visiting Committee's inspections when, after a general cleaning, the normal odour was masked by bucketfuls of disinfectant. ${ }^{30}$

29 Procedural legislation frequently provides for committal to "a mental hospital, prison or other suitable place of safe custody ... ". LAWS OF SIERRA LEONE c. 39, \$64(4) (1960). Cf. Ghana Criminal Procedure Code \$133(5) (1960); Nigeria Criminal Procedure Act, $\$ 222$ (1963); Laws of UGANDA c. 24, §162(5) (1951); LAWS OF ZANZIBAR c. 14, \$156(5) (1961). Where the medical facilities are inadequate, the legislation may simply call for committal to prison. E.g., LAws of BECHUANALAND c. 18, §§169(1), (2) (1959). The order made by the Nyasaland Figh Court in Regina v. Alidia, [1959] 1 Rhod. \& Nyas. I.R. 221, 224, is typical:

It is hereby ordered that the Accused person be kept in custody as a criminal lunatic in the Mental Hospital at Zomba, or if suitable accommodation is not available at the Mental Hospital at Zomba, then in the Central Prison at Zomba, until such time as the wishes of the Governor are made known.

30 ENAHoRo, FugITTE OfFender 92-93 (1965). The use of chains and other restraints, frequently without reason and without the keeping of proper records, was the subject of official report in Nigeria at this time. See PATERSON, A REPORT to His Excellency te Governor of Nigeria on CrIMe and Its Treatament in the Colony and Protectorate $\llbracket 12$ (1944). 
If the "Iunatic" is incapacitated, he may be found sitting under a convenient shade tree in the prison yard; if he is violent, he may be chained. $^{31}$ Provision for the transfer to a hospital of prisoners who are in need of treatment exists in all prisons legislation, but for obvious reasons the procedure is not extensively used..$^{32}$

In the former British colonies, the utter inadequacy and inhumanity of this situation has constantly been reiterated. ${ }^{33}$ But only slowly, as other facilities have become available, have the mentally ill been moved out of the prison systems. In Nigeria, generally regarded as having better facilities than most independent African countries, prison reports from 1950 to 1960 show that at the end of each year there were more than four hundred mentally abnormal prisoners in the population of the federal prison system alone (that is, not including the local authority systems in Western and Northern Nigeria). On the average, two hundred fifty of this number each year were civilly committed. ${ }^{34}$

The situation is distressing enough on its own account. It is perhaps more distressing when considered together with its implications for the legal adjudication of responsibility. To this problem we now turn.

\section{Psychiatry and the Courts}

How far psychiatric experience can be utilized by the courts will obviously be governed by the availability of the facilities already discussed. Provisions referring to its use-in pre-trial examinations, in trial determinations of responsibility and in various post-sentence procedures-are not designed to reflect the regular availability of medical or psychiatric services in Africa but rather to give official idealized recognition to their role and to lay the groundwork of machinery which would become more a reality in the future.

31 The barbarism is not necessarily colonially inspired. Prince has pointed out that traditional healers frequently resort to chaining their patients to prevent injury. Prince, supra note 6 , at 117.

32 E.g., Kenya Prisons Ordinance, $\$ 39$ (1963) ; Lrberian Code of Laws c. 8, $\S 737$ (1956); Nigeria Prisons Act, $\$ 19,21$ (1960); Rhodesia \& Nyasaland Prisons Act, $\$ \$ 72,73$ (1955) (now in force in Southern Rhodesia and Malawi); Mental Disorders Act, Act No. 38 of 1916, $\$ 40$ (So. Afr.) ; Zambia Prisons Act, $\$ \$ 70-71$ (1965). LAws of UGANDA c. 59, §58 (1951), provides that persons of unsound mind shall only be kept in prison long enough to effect certification, then transferred to a mental hospital.

33 See Advisory Committee on the Treatment of Offenders in the Colonies, Memorandum on the Treatment of OfFenders $\llbracket 49$ (1954). The recommendations of the Colonial Secretary's Consultant Psychiatrist for the reorganization of the Nigerian system are referred to in that country's ANNUAL REPORT ON TEE TREATASENT OF OFFENDERS (1956-57). Not a great deal has since been done to implement them.

34 The 1960-61 Report (made during the first year of independence) is the last to be published. ANNuAL REPORTS OF THE FEDERAL PRISONS DeParTMENT (1958-61); AnNual Reports of the Treatment of OfFenders (1950-57). 
The realities of medical practice at the present time are such that the minute number of psychiatrists, burdened with heavy hospital and administrative duties, cannot give much of their time to forensic psychiatry no matter how anxious they may be to do so. In general, where there are psychiatrists in an African country, they provide services only for the courts in the immediate vicinity, usually only in criminal cases, seldom in noncapital or at least nonviolent cases and irregularly with respect to capital crimes and offenses of serious violence. It is probably true that a psychiatric opinion can be obtained in the majority of capital cases-usually murder cases ${ }^{35}$-in which it is requested, though sometimes the sheer physical difficulties involved in getting to see patients make it impracticable. ${ }^{36}$ And usually, of course, no more than one expert opinion will be available, making the conflict between expert witnesses in psychiatric matters an uncommon experience in African courts.

\section{A. The Accused's Fitness To Make His Defense}

If an accused person is not so manifestly deranged that he is removed to safe custody before his trial, the first occasion on which his sanity will come under consideration will be when he is brought to trial. At that stage, the issue will not be whether he was of unsound mind at the time of the offense, or even whether he is now of unsound mind, but rather whether he is fit to stand trial. No psychiatric standard is set here; the anglophonic African jurisdictions have followed the English pattern and established simple functional tests which can be applied by the courts without expert assistance.

An accused person is unfit to be tried if he cannot understand the charge against him, cannot follow or appreciate the proceedings in court or cannot instruct his advisers so that his defense may properly be prepared. ${ }^{37}$ Incapacity in any one of these respects will render him unfit to be tried and the mere fact that in lucid moments he appreciates what is being said against him will not make him fit. ${ }^{38}$ Similarly, if the accused satisfies all three tests but cannot make a positive defense

35 The death penalty is commonly mandatory for murder. See p. 1165 infra. One consequence of this is that defendants are commonly advised to plead insanity only in defense to murder charges; in other cases, ordinary imprisonment or any lesser sentence may well be preferable to inadequate and indefinite treatment for mental illness.

36 I personally know of the refusal of an African psychiatrist's request to see all charged murderers, on the grounds that distances were too great and security arrangements too tenuous. A judge warned the same psychiatrist that he would kill himself with work if he tried to carry out any such project.

37 Regina v. Podola, [1960] 1 Q.B. 325; Kaplotwa s/o Tarino v. Regina, [1957]

E. Afr. L.R. 553 (Kenya); Regina v. Mudia, [1954] No. Rhod. L.R. 302.

38 Kaplotwa s/o Tarino v. Regina, supra note 37. 
for some other reason-for example, amnesia caused by supervening psychosis ${ }^{39}$ or head injury ${ }^{40}$ - he will not be deemed unfit for trial.

There are no African Briggs Laws and few mandatory procedures for calling medical evidence in any type of case. Most of the provisions simply instruct the courts to inquire into the accused's fitness without specifying how it shall be done ${ }^{41}$ but it is common practice to fulfill the obligation by remanding for medical observation and report. ${ }^{42}$ Ghana ${ }^{43}$ and Nigeria ${ }^{44}$ both have made medical evidence a prerequisite for a finding of unfitness-one assumes that this will be psychiatric evidence only in a small proportion of cases-but elsewhere there is no obligation to call such evidence even if it is available. ${ }^{45}$ The courts, too, have not been slow to emphasize that the question of fitness should not be determined solely on the basis of expert evidence when it is called. ${ }^{46}$ Experience suggests that in this context there is considerable likelihood that psychiatric evidence will assume a minor role at the side of the court's power to ask questions of the accused, hear his answers and observe his demeanor.

A finding of unfitness to be tried results in the suspension of further proceedings and either the detention of the accused ${ }^{47}$ or in some countries his conditional release if the offense charged is bailable and he is not dangerous and can safely be given into the custody of relatives or friends. ${ }^{48}$ When he is reported to be recovered the trial may be

39 Regina v. Njiri, [1959] 2 Rhod. \& Nyas. L.R. 241 (So. Rhod.).

40 Regina v. Phiri, [1958] Rhod. \& Nyas. L.R. 1008 (No. Rhod.).

41 Laws of SierRa LeoNe c. 39, \$64(1) (1960); Laws of UgaNda c. 24, § 162(1) (1951); LAWS OF ZaNzIBAR c. 14, \$156(1) (1961).

42 See, e.g., Regina v. Nyasulu, [1956] Rhod. \& Nyas. L.R. 633 (Nyas.), setting out the practice for that country.

43 Ghana Criminal Procedure Code § 133(1) (1960).

44 Nigeria Criminal Procedure Act, $\$ 223(3)$ (1963) ; Northern Nigeria CrIMInal Procedure Code \$ 320(3) (1963).

45 Singh s/o Singh v. Regina, [1958] E. Afr. L.R. 28 (Kenya). If the defense fails to call such evidence, knowing that it is available, it will not then be allowed to claim that there was insufficient inquiry into the accused's mental condition. The position in Liberia is uncertain; it appears that in theory there must be medical evidence before a finding of mental illness for any purpose. See p. 1157 infra.

46 See, e.g., The Queen v. Madugba, 3 Fed. Sup. Ct. 1 (Nig. 1958) ; Regina v. Mandala, [1957] Rhod. \& Nyas. L.R. 251 (Nyas.).

47 For the place of detention, see note 29 sipra.

48 E.g., Ghana Crimunal Procedure Code $\$ 133(3)$ (1960); Nigeria Criminal Procedure Act, §225(1) (1963); Northern Nigeria Criminal Procedure Code \$ 322 (1963); LAWS OF SIERRA LEONE c. 39, §64(3) (1960); Mental Disorders Act, Act No. 38 of $1916, \S 40$ (So. Afr.); LAWS of UGANDA c. 24, $\$ 162(3)$ (1951); Laws of ZanzIBAR c. 14, § 156(3) (1961). The statement in Rex v. Sepetsi, [1927] So. Afr. L.R., O.P.D. 312, that a finding of mental disorder under $\$ 28$ of the Mental Disorders Act absolves the accused from all further proceedings, appears to be based on the misinterpretation of the section, which applies to those initially unfit to stand trial and not to those raising insanity as a substantive defense. Section 36 allows the resumption of the trial following recovery. 
resumed, and though in practice the normal delay will be several months, it is clear from the reported authorities that the length of permissible delay cannot be the subject of complete generalization. ${ }^{49}$

Several countries have been troubled by the proper disposition of cases involving the deaf mute. The complicating factors peculiar to Africa are, once again, the shortage of psychiatric facilities to assist diagnosis-particularly valuable where the disability has existed since birth, the considerable likelihood that the accused will be illiterate and therefore unable to respond to written information and questioning and his frequent isolation from his family or friends who will have established means of communicating with him. It is clear that if contact and comprehension can be established at all, the courts have a duty to inquire fully into the ways in which these can be accomplished, ${ }^{50}$ and, if accomplished, to proceed with the trial if the criteria for fitness to plead are satisfied. What will happen if the accused cannot be tried will depend on the jurisdiction.

The English-inspired criminal procedure codes are often of little specific help, since the English precedents provided only for the disposition of the mentally disturbed offender whose fitness to plead was questioned. The English courts were therefore forced into the bizarre position of classifying the deaf mute as mentally disordered. ${ }^{51}$ The South African Criminal Procedure Act and its variants in the other countries of Southern Africa have adopted the same format. ${ }^{52} \mathrm{Ex}$ tensive criticism, ${ }^{53}$ however, has led the courts of Southern Rhodesia to the point of refusing to commit an apparently sane person to psychiatric custody. ${ }^{54}$ The current South African solution appears to

49 E.g., Sudan Gov't v. Khalid, [1962] Sudan L.J.R. 115 (21/2 years).

50 The duty and the procedure to be followed in fulfilling it are set out in Leseroi v. Regina, [1964] E. Afr. L.R. 111 (1963) (Kenya); Rex v. Katete, 6 Uganda L.R. 200 (1948).

51 Rex v. Governor, [1909] 2 K.B. 81, on the interpretation of the Criminal Lunatics Act, 1800,39 \& 40 Geo. 3, c. 94, \$2; cf. Archrold, Criminal Pleading, Practice and Evidence $\$ \$ 464-65$ (35th ed. 1962). Modern legislative reform does not appear to have changed the position for the Criminal Procedure (Insanity) Act, 1964, although referring to the case of an accused under a "disability" preventing trial, $\$ 4(1)$, then provides in $\$ 5(1)$ that the court shall order such a person to be "admitted to such hospital as may be specified by the Secretary of State." Discharge will then be in the discretion of the Secretary of State.

52 Laws of Bechuanaland c. 18, $\$ 163,169$ (1959); South Africa Criminal Procedure Act, $\$ 164$ (1957); Mental Disorders Act, Act No. 38 of 1916, $\$ 28$ (So. Afr.) ; Southern Rhodesia Mental Disorders Act, 1936, \& 30; Rex v. Mamyila, [1913] So. Afr. L.R., T.P.D. 464.

53 E.g., 1 Gardiner \& Lansdowne, South African Criminal Law and ProCEDURE 91-92 (6th ed. 1957); see notes 54 \& 55 infra.

54 In re Pupu, [1959] 1 Rhod. \& Nyas. L.R. 377 (So. Rhod.). The Attorney General finally did not oppose the discharge from mental hospital, committal to prison and later discharge. It does not appear that the trial judge's call for amending legislation has yet been acted upon. 
be to hold that their legislation gives them sufficient leeway to commit such a person to prison pending the President's instructions. ${ }^{55}$

The codes which follow the early Colonial Office pattern ${ }^{56}$ either provide specifically for the sane but unfit accused to "be treated in like manner as a person incapable of making his defence by reason of unsoundness of mind" or allow him to be treated in this way in default of specific provision. These codes obviate, however, the difficulties of the situation by providing for his discharge to the custody of friends or relatives if he can properly be cared for and is not dangerous to himself or others.

Only the East African countries have legislated a special procedure for this type of case. Provided that there is a finding that the accused committed the act alleged, he will be detained in prison pending a further order. ${ }^{57}$ This power appears to be used sympathetically, in an attempt to handle the social situation in its entirety, so far as it is possible to do so with limited resources. It has been used, for instance, to insure the safe custody of an accused while arrangements were made for his future welfare-in terms of employment, guidance and supervision-when he had no home and no one to care for him. ${ }^{68}$

\section{B. The Defense of Mental Disorder}

The common law jurisdictions of Africa are haunted by the ghost of Daniel M'Naghten. They, or the British Colonial Office before them, have put the M'Naghten rules-more or less-into statutory form in their criminal codes. Even where it has been less rather than more, the English-trained, M'Naghten-oriented judges have often slipped into the familiar habit of reading the codes as if they simply restated English law. ${ }^{59}$ At various times the M'Naghten formulation

55 State v. Maxamba, [1964] 1 So. Afr. L.R. 645. Section 28 of the Mental Disorders Act, Act No. 38 of 1916 (So. Afr.), the machinery of which is incorporated into $\$ 164$ of the Criminal Procedure Act, 1955, refers to committal to "a gaol or institution." See also the English legislation, note 51 sitpra.

56 E.g., Nigerian Criminal Procedure Act, $\$ \$ 225-35$ (1963) (in force in the southern areas of the country); Northern Nigeria CrIminal Proceddure CoDE $\$ 261$ (1963); LAws of SiERRA LEONE c. $39, \$ \S 64-69$ (1960); see Zaria Native Authority v. Bakori, [1964] No. Nig. L.R. 25.

57 Leseroi v. Regina, [1964] E. Afr. L.R. 111 (1963) (Kenya); Regina v. Tselize, [1956] Rhod. \& Nyas. L.R. 232 (Nyas.); Malawi Criminal Procedure Act, $\$ 167$ (1951); Laws of UGANDA c. $24, \$ 167$ (1951); Laws of ZaNzIBAR c. 14, \$161 (1961).

58 Regina v. Tselize, supra note 57.

59 The familiar habit is too common to be documented. Recent illustrations of its effect in African criminal statutory interpretation are given in OKONKWo \& NAISH, CRIMINAI LAW IN NIGERIA 72-95 (1964) (mens rea); Naish, $A$ Redefinition of Provocation Under the Criminal Code, 1 NrG. L.J. 10 (1964) (provocation); Seidman, Intent and the Law of Murder, 1 U. GhaNA L.J. 73 (1964) (mens rea); Seidman, Witch-Murder and Mens Rea: A Problem of Society Under Radical Social Change, 28 MODERN L. REV. 46 (1963) (mens rea). 
has been read into statutes in which it never actually appeared, ${ }^{60}$ it has been used to give a gratuitous display of the bench's comparative knowledge ${ }^{61}$ and it still lingers in the minds of some lower court judges (who are fortunately now being more regularly reversed) as a standard of decision preferable to the statutory formulae actually in force. ${ }^{62}$

In fact the M'Naghten rules appear in their original pristine inadequacy in only one African country, Sierra Leone, which has adopted English criminal law in a piecemeal, uncodified form. ${ }^{63}$ Elsewhere, the several different presentations of the original rules fall simply into the categories of those which have taken approximately the M'Naghten tests and those which have modified them.

Before dealing with these, however, we may conveniently discuss the preliminary question of how far the actual description of mental disorder itself has been modified in the African codes. The M'Naghten rules themselves spoke in terms of a "defect of reason" caused by "disease of the mind" as the mental condition on which the defense was to be based. The principal hazard in this terminology was its vagueness and the resulting uncertainty about the place of subnormality, neurosis, psychopathy, neurological disorders and other organic disorders of the brain under the rules. Over a century of amplification in the English courts led to the inclusion of subnormality within the defense as a matter of practice, ${ }^{64}$ the inclusion of neurological and other organic conditions as a matter of law ${ }^{65}$ and the probable exclusion of neurosis and psychopathy. ${ }^{66}$

Even before these developments had crystallized, the British government had become sufficiently aware of the deficiencies of the M'Naghten formulation to make some changes in the codes given to the Empire. The Indian Penal Code, the original draft of which

60 E.g., Rex v. Ross, 14 Kenya L.R. 148 (1932); Nyinge s/o Suwatu v. Regina, [1959] E. Afr. I.R. 974 (Kenya); Rex v. Bargutwa, 6 Ct. App. E. Afr. 142 (Kenya 1939); Rex v. Gerevasi s/o Lutabingwa, 9 Ct. App. E. Afr. 56 (Tang. 1942).

61 Rex v. Omoni, 12 Sel. Judg. Ct. App. W. Afr. 511 (Nig. 1949); Rex v. Nasamu, 6 Sel. Judg. Ct. App. W. Afr. 74 (Nig. 1940); Sudan Gov't v. Ishag, [1958] Sudan L.J.R. 1.

62 E.g., Regina v. Frafra, [1959] Ghana L.R. 442; Regina v. Tembo, [1961] Rhod. \& Nyas. L.R. 858 (No. Rhod.).

63 Elias, Ghana and Sierra Leone 304 (1962).

64 Royal Comarission on Capital Punishment, 1949-53 Report 119 (1963).

$65 I d$. at 132-35 (epilepsy) ; Bratty v. Attorney Gen., [1963] A.C. 386 (psychomotor epilepsy); Regina v. Kemp, [1957] 1 Q.B. 399 (cerebral arteriosclerosis).

${ }^{66}$ E.g., Royal Commission on Capital Punishment, op. cit. supra note 64, at 73-74 (definition of "mental disease") ; id. at 135-40 (psychopathy). In Attorney Gen. v. Gallagher, [1963] A.C. 349, however, at least two of the Lords of Appeal appear to have contemplated the possibility that a psychopathic condition could come within the scope of the M'Naghten defense. 
in fact antedated $M$ 'Naghten, ${ }^{67}$ provided the all-inclusive phrase "unsoundness of mind" "68 which was later adopted by Northern Nigeria; ${ }^{69}$ it is rivalled in completeness only by the Sudanese "permanent or temporary insanity or mental infirmity." 70 Slightly less comprehensive is Southern Nigeria's "state of mental disease or natural mental infirmity," "71 and more explicit-but probably for that very reason unsatisfactory-are Ghana's "idiocy, imbecility, or any mental derangement or disease affecting the mind" 72 and Liberia's "idiot, imbecile, lunatic, or insane person." 73 The latter two presumably limit the defense to the low-grade defectives specified and exclude by omission the higher-grade defectives who might otherwise take advantage of it.

The East and Central African codes, together with the RomanDutch laws of Southern Africa, have retained the "disease" concept. The Colonial Office used as its East and Central African model the English draft code of 1879, in which Sir James Stephen had formalized the M'Naghten rules. ${ }^{74}$ The only easing of the confusion about the significance of "disease" has come through the decision of the Eastern African Court of Appeal according subnormality the legal, if not the

67 The draft was originally submitted in 1837 and then underwent revision before being put before the Legislative Council and passed in 1860. RANCHODDAS \& THAKORE, The Law of Crimes 1 (19th ed. 1956).

68 Indian Penal Code \$ 84.

69 Northern Nigeria Penal Code $\$ 51$ (1959).

70 Sudan Penai Code $\S 50$ (1925).

TI Southern Nigeria Criminala CoDe $\$ 28$. "Natural mental infirmity" refers to subnormality. Rex v. Omoni, 12 Sel. Judg. Ct. App. W. Afr. 511 (Nig. 1949); The Queen v. Tabigen, 5 Fed. Sup. Ct. 8 (Nig. 1960).

72 Ghana Criminal Code $\S 27$ (1960). At the time the Code was first promulgated in 1892 the only official English categorization of mental defectives was that into "idiots" and "imbeciles" by the Idiots Act, 1886. Within a few years, a Royal Commission undertook the first full inquiry into mental deficiency and its management, and the 1913 English legislation recognized four categories of defectives-idiots, imbeciles, feeble-minded and moral defectives. Although the original intention in 1892 may have been for the Ghanaian provision to cover all classes of defectives, by the time the code was reenacted in 1960 , it is clear that its terminology did not.

73 LiberIAN CODE OF LAwS c. $27, \S 15$ (1956). With the exception of one sentence, this was based on the New York provision (now N.Y. PeNaL LAw § 1120). The New York history appears to resemble that given for England in note 72 supra. In the early nineteenth century (at the time the Liberian law was being developed), "idiocy" was recognized by the New York courts as a distinct classification and "imbecility" was a blanket term covering all other weakness of intellect. See, e.g., Blanchard v. Nestle, 3 Denio 37 (N.Y. Sup. Ct. 1846) ; Stewart's Executor v. Lispenard, 26 Wend. 253 (N.Y. Sup. Ct. 1841); Odell v. Buck, 21 Wend. 141 (N.Y. Sup. Ct. 1839). By the beginning of this century, it was recognized that there were mental defectives who were not "imbeciles" and who could therefore not have the benefit of the defense under the Penal Law. See, e.g., People v. Moran, 249 N.Y. 179, 103 N.E. 553 (1928) ; People v. Farmer, 194 N.X. 251, 87 N.E. 457 (1909). Following the adoption of mental deficiency legislation, the courts recognized at least three categories of defectives-idiots, imbeciles and morons. People v. Hoffman, 255 App. Div. 404, 8 N.Y.S.2d 83 (1938).

74 See also Stephen, Criminat Law 20-22 (6th ed. 1904); 2 Stephen, A History of the Criminal Law of England 149 (1883). 
medical or logical, status of a disease for these purposes. ${ }^{75}$ South Africa has adopted the conceptions of what its leading criminal law textbook calls "disease of the mind or mental defect," 76 although the same authority states categorically:

For legal purposes no distinction is to be drawn between idiocy, lunacy, mania, paranoia, melancholia, hypochondria, dementia, or any other species into which the various forms of mental aberration or defect may be classified by medical scientists ... ${ }^{77}$

The Appellate Division has at least denied to a psychopathic condition the status of a mental disorder. ${ }^{78}$ Organic conditions have been included within the scope of a defense. ${ }^{79}$

The adoption of the English draft code in the East and Central African jurisdictions has resulted, too, in the enactment of another of Sir James Stephen's emendations. Aware of the controversies which had surrounded the $M^{\prime} N$ aghten rules as to whether the judges were trying in 1843 to define insanity as a whole or merely to define that area of mental illness which would exculpate from crime, he stated his interpretation for the avoidance of further doubt. Appended to each statement of the responsibility rule, therefore, is the following:

But a person may be criminally responsible for an act or omission, although his mind is affected by disease, if such disease does not in fact produce upon his mind one or other of the above effects mentioned [i.e., ignorance of what he is doing or of the wrongness of what he is doing] in reference to that act or omission. ${ }^{80}$

\section{Approximate $M$ 'Naghten}

The original $M^{\prime}$ Naghten rules were expressed as five questions. They posed two separate responsibility tests: the cognitive tests applicable in the case of a person who sets up the defense of insanity when suffering from a disease of the mind ("insane delusion respecting one or more particular subjects or persons" in the language of the original question) and a distinct test for a person suffering only from

75 Oyee s/o Duru v. Regina, [1959] E. Afr. L.R. 407 (Uganda).

761 GARDINER \& LANSDOWNE, op. cit. supra note 53 , at 87 .

$77 \mathrm{Id}$. at 89.

$78 \operatorname{Rex}$ v. Kennedy, [1951] 4 So. Afr. L.R. 431.

79 E.g., Rex v. Anderson, [1928] So. Afr. L.R., C.P.D. 195 (encephalitis lethargica).

${ }^{80}$ E.g., Kenya Penal Code $\$ 13$; Uganda Penal Code \$12; Zambia Penal CoDE § 13; LAWS OF ZANZIBAR c. 13, §12(2) (1961). 
a "partial delusion" ("an insane delusion as to existing facts"). Following the Stephen formulation, eight countries have adopted the cognitive tests as their only basis for decision. Eleven others have incorporated them into their statutory schemes in some form or other, though not as the exclusive criteria. Only Ghana ${ }^{81}$ and the Sudan $^{82}$ have modified them by leaving out all reference to the accused's knowledge of the wrongfulness of the actions.

Hence, no reference to delusions appears in the legislation of eight countries, primarily those of East and Central Africa. The cognitive tests are expressed in these terms:

A person is not criminally responsible for an act or omission if at the time of doing the act or making the omission he is through any disease affecting his mind incapable of understanding what he is doing, or of knowing that he ought not to do this act or make this omission. ${ }^{83}$

The question to be asked for survey purposes is how far the absence of provisions incorporating the delusion test narrows the defense. One must assume that an interpretation which reads the delusion test into the legislation when it has been omitted is not legitimate. ${ }^{84}$

Stephen certainly did not think that by leaving out all reference to partial delusions he was narrowing the defense. Unlike the great majority of his contemporaries on the English bench, he was not content with the idea that a man could be free from mental disorder and yet still suffer delusions limited to particular matters. ${ }^{85}$ His own opinion was that delusions were relevant to the issue of mental illness not merely with respect to the content of the delusion, ${ }^{86}$ but either as evidence of the illness or as evidence that the accused's cognitive faculties were impaired. ${ }^{87}$

81 Ghana Criminal Code $\$ 27$ (1960). The offender will be excused if he either does not know the nature or consequences of the act or is so deluded as to make him an unfit subject for punishment. Seidman, Insanity as a Defence Under the Criminal Code, 1 U. GranA L.J. 42, 46-47 (1964) suggests that the use of the word "consequences" in the test has the effect of bringing into issue the defendant's capacity to control his conduct. It is hard to agree; the scope of the cognitive test is admittedly expanded but still remains at no more than a cognitive level.

82 Sudan Penal Code $\$ 50$ (1925). The offender will be excused if he does not possess the power to appreciate the nature of his acts or to control them.

83 See statutes collected at note 80 supra.

84 For examples of this construction, see Rex v. Bargutwa, $6 \mathrm{Ct}$. App. E. Afr. 142 (Kenya 1939); Rex v. Gerevasi s/o Lutabingwa, 9 Ct. App. E. Afr. 56 (Tang. 1942).

852 Stephen, A History of the Criminal Law of England 160-65 (1883).

86 Under the M'Naghten formulation the accused "would be considered in the same situation as to responsibility as if the facts with respect to which the delusion exists were real."

872 STEPHEN, op. cit. supra note 85, at 160-65. 
Today, whenever there is any expert testimony available, it seems unlikely that the courts will resort to the partial delusion test even where it is present in the legislation. In Nigeria, for example, where it is specifically included in the Criminal Code, insanity defenses will commonly be based on the cognitive tests where the facts indicate paranoia or other delusion. ${ }^{88}$ And under the Stephen-inspired codes it has been held to be perfectly appropriate for a deluded person to be dealt with under the cognitive tests. ${ }^{89}$

\section{M'Naghten Modified}

Of the three principal modifications which have been made in the $M^{\prime}$ Naghten formula in Africa, the first is basic to the scope of the cognitive tests.

Although the original rules suggested that inability to know either the unlawfulness or the general wrongfulness of the action would support the defense, the modern English interpretation is in the direction of allowing a finding of irresponsibility only if the accused does not know that his act is unlawful.90 In reliance on the modern English authority and overlooking East African authority in favor of the older view, ${ }^{91}$ the East and Central African courts have held the same, ${ }^{92}$ despite the intention of the original draftsman to keep the broader interpretation..$^{93}$

Only South Africa appears to have kept the broader interpretation as a result of judicial decision, ${ }^{94}$ but Northern Nigeria has again followed the Indian model and granted the exemption to one who is "incapable of knowing . . . that he is doing what is either wrong or contrary to law." ${ }^{95}$ To say, though, that the defense is broadened is to use a very relative term. Since we are dealing here with a minute percentage of those who are mentally abnormal any broadening of the rule which is expressed only in terms of cognition will extend it only

88 See, e.g., Echem v. The Queen, 14 Ct. App. W. Afr. 158 (Nig. 1952) ; Rex v. Omoni, 12 Sel. Judg. Ct. App. W. Afr. 511 (Nig. 1949) ; Rex v. Inyang, 12 Ct. App. W. Afr. 5 (Nig. 1946).

80 See, e.g., Regina v. Tembo, [1961] Rhod. \& Nyas. L.R. 858 (No. Rhod.); Regina v. Magata s/o Kachehakana, [1957] E. Afr. L.R. 330 (Üganda).

90 Rex v. Codere, 12 Crim. App. R. 21 (1916) ; Regina v. Windle, [1952] 2 Q.B. 826. The pre- and post-M'Naghten authorities adopting the broader view are reviewed in Stapleton v. The Queen, 86 Commw. L.R. 358 (1952), in which the High Court of Australia refused to follow the Windle decision. See also Morris, "Wrong" in the McNaughten Rules, 16 ModERN L. REv. 433 (1953).

01 See, e.g., Rex v. Kamau s/o Njeroge, 6 Ct. App. E. Afr. 133 (Kenya 1939). 92 Muswi s/o Musele v. Regina, 23 Ct. App. E. Afr. 622 (Kenya 1956); Golowa v. Regina, [1964] Rhod. \& Nyas. L.R. 17 (No. Rhod.).

03 2 STEPHEN, op. cit. supra note 85, at 167.

941 GARDINER \& LANSDOWNE, op. cit. supra note 53, at 90.

05 Northern Nigeria Penal Code § 51 (1959). 
slightly. Nonetheless, it is clear that some fact situations will fall within the defense which would not be allowed to form the basis of the narrower defense. In Muswi s/o Musele v. Regina, ${ }^{96}$ for example, the accused killed his wife believing that she was bewitching him, knowing that it was illegal to do so but being confused as to the morality of the act. The East African Court of Appeal held that on these facts the accused did not satisfy the narrower formulation of the test, but it seems fairly clear that his confusion as to the rightness or wrongness of what he was doing would afford him a defense had he been tried in Northern Nigeria or South Africa.

The second modification, copied from West Indian codes, is in Africa peculiar to Ghana. As we have seen, Ghana has adopted a description of mental disorder which is full in some respects but perilously limited in respect of subnormal conditions, and has abandoned the knowledge of wrongfulness as a criterion for decision. It has taken further its policy of broadening the defense by adding as an apparently complete alternative a test based on functional appreciation of the significance of delusions. The defense of insanity will be available to an accused person

if he did the act in respect of which he is accused under the influence of an insane delusion of such a nature as to render him, in the opinion of the jury or of the court, an unfit subject for punishment of any kind in respect of such an act. $^{\text {.7 }}$

This appears to mean that where the accused's mental condition makes punishment futile-presumably because he cannot be deterred and because he would not have committed the act if he had not been deluded-he should be exempted from it. This interpretation, suggested in an editorial note in the West African Law Reports in 1957,98 was later adopted by the Ghana Court of Appeal in 1959.99 It was reversed in 1960 in favor of a M'Naghten-inclined interpretation that the delusion should be such that if the imagined facts were true, they would provide justification for the action taken. ${ }^{100}$

This interpretation is clearly possible. The judge or jury are given a discretion to exempt whomsoever they feel is unfit to be punished and are entitled to set up guidelines for the exercise of their discretion. At the same time, bearing in mind that the guidelines

9623 Ct. App. E. Afr. 622 (Kenya 1956).

97 Ghana CrIminal Code $\$ 27(2)$ (1960).

98 Regina v. Grumah, [1957] 2 W. Afr. L.R. 255 (Ghana 1957). The question of interpretation was not raised at all in the actual report.

99 Regina v. Moshie, [1959] Ghana L.R. 343.

100 Degarti v. Regina, [1960] July-Dec. Cycl. Judg. Crim. 120 (Ghana). 
chosen are those of the M'Naghten formulation, it would appear a little strange that if they were intended they were not specified as such in the legislation. A later Court of Appeal has now held that the broad phrasing of the section is intended to confer a broad discretion which is to be exercised not in terms of the nature of the delusion but in accordance with the judge's or jury's assessment of the seriousness of the accused's illness. ${ }^{101}$

Finally, half a dozen countries have taken the first conservative step toward undermining the hold of $M^{\prime} N a g h t e n$ on African criminal law. South Africa and the neighboring countries of southern Africa ${ }^{102}$ have recognized the "dangerous doctrine" of irresistible impulse as an overlay upon the M'Naghten rules, despite the persistent opposition to the extension by the English courts. ${ }^{103}$ Nigeria and the Sudan ${ }^{104}$ have specifically legislated in favor of the offender who is deprived by his mental illness of the capacity to control his actions, thus avoiding the implication of sudden impulsiveness of action but still carrying the overtones of total deprivation of will power which will be found, on an honest view of the facts, only in a few cases. Nonetheless, although the form of the development has been criticized in recent years, it represented at the time of its first enactment a considerable step forward in the handling of the mentally abnormal offender and still, in the African context, offers greater freedom to defendants in these few jurisdictions than is available to those in the rest of the continent. ${ }^{105}$

\section{Evidence of Mental Disorder: the Procedural Problems}

Establishing mental disorder of a sort that will bring a defendant within the exempting provisions of the law leads to a finding of "guilty but insane" and the placing of the accused at the disposal of the

101 Akpawey, Crim. App. No. 159/65 (Ghana 1965); Bodie, Crim. App. No. 31/63 (Ghana 1964). I am indebted to Professor R. B. Seidman of the University of Ghana for the first citation. On the Ghana provision see generally Seidman, supra note 81 .

102 Regina v. Koortz, [1953] 3 So. Afr. L.R. 303; Regina v. Hay, [1899] Sup. Ct. 290 (So. Afr.); Rex v. Sprighton, [1939] So. Rhod. L.R. 34.

103 The English courts and the Privy Council have vigorously opposed the "dangerous doctrine" and "fantastic" "subversive" theory. Sodeman v. Rex, [1936] 2 All E.R. 1133; Rex v. Kopsch, 19 Crim. App. R. 50 (1925); Regina v. Haynes, [1859] 1 F. \& F. 666; Attorney Gen. v. Brown, [1960] A.C. 432 (Austl.). Section 2 of the Homicide Act, 1957, now effectively allows a defense in the case of most manifestations of inability to control behavior.

104 Nigeria Criminal Code $\$ 28$ (1958); Sudan Penal Code $\$ 50$ (1925).

105 Despite Stephen's hope that uncontrollable behavior would be covered by the cognitive tests, see 2 STEPEEN, op. cit. supra note 85, at 167 , the East and Central African courts have uniformly held that it is not. Regina v. Phiri, 5 No. Rhod. L.R. 186 (1954); Rex v. Shekanga s/o Ndeka, $15 \mathrm{Ct}$. App. E. Afr. 158 (Tang. 1948); Rex v. Weraga s/o Wamala, 10 Ct. App. E. Afr. 48 (Uganda 1943). 
state. ${ }^{106} \mathrm{He}$ cannot, if his offense is capital, be executed, nor in theory can he be made subject to the normal primitive processes of imprisonment. He must be detained as a mentally abnormal offender, given periodic medical examination ${ }^{107}$ and considered for release only when it is certified that he is no longer suffering from disorder, though even then discharge will not follow automatically. ${ }^{108}$ In ideal circumstances, he would always be detained for treatment in a mental hospital; in reality, as we have seen, he may receive considerably less than ideal treatment.

Whatever the state's interest in bringing penal consequences to bear only on the responsible and securing treatment only for those deemed to need it, we are here considering, in adversary terms, a defense to a criminal charge. In the ordinary course of events, counsel for the accused will determine whether or not the defense should be raised at all - and with the prospect of indeterminate detention following a successful defense, it normally will be raised only to avoid the possibility of the death penalty - and will introduce testimony to substantiate it. Indeed, since there is in each jurisdiction only one codified defense based on mental disorder, unlike England, for example, where defenses based on M'Naghten and "diminished responsibility" are alternatives in murder cases and the prosecution may rebut either defense by producing evidence that the accused is within the other, ${ }^{109}$ the courts incline to the view that only the accused can properly produce evidence of disorder. ${ }^{110}$ To hold otherwise, it is said, would

106 See, e.g., Laws of Bechuanaland c. 18, \& 169(2) (1959); Grana Criminal Procedure Code $\$ \S 137$ (2), (3) (1960); KenYa Criminat Procedure Code $\$ 166$ (1) (1951) ; Mental Disorders Act, Act No. 38 of 1916, \&29 (So. Afr.) ; Laws of UGANDA c. $24, \S 166(1)$ (1951); LAws of ZaNZIBAR c. 154, $\$ \$ 160(1)$, (2) (1961). Nigeria uses the terminology of "acquittal" on the ground of mental disorder, but there is still a mandatory committal if the court finds that the accused actually did the act alleged. Nigeria Criminal Procedure Act, $\$ \S 229-30$ (1963); Nortmern Nigeria CRiminal Procedure Code $\$ \S 326-27$ (1963).

107 South Africa's Mental Disorders Act, Act No. 38 of 1916, $\S 25,38$, has the most complete obligatory report procedure, requiring annual reports during the first three years and reports in the fifth and every succeeding fifth year. Kenya and Uganda call for a report on mental condition to be made to the executive three years after committal and every two years thereafter. KenYa Criminal Procedure Code $\$ 166(2)$ (1951); LAws of UGANDA c. $24, \S 166(2)$ (1951). The Nigerian codes require medical officers to report whenever requested by the executive. Nigeria Criminal Procedure Act, $\$ 231$ (1963); Northern Nigeria Criminal Procedure CODE $\$ 328$ (1963).

108 The discharge procedures are usually the same as those following the recovery of a person originally found unfit to make his defense. See pp. 1144-46 supra. In some jurisdictions, the judicial authority may impose limitations on release at the time of original committal. See, e.g., Sudan Gov't v. Hamad, [1961] Sudan L.J.R. 232 (no release without reference back to the court).

109 Bratty v. Attorney Gen., [1961] 3 All E.R. 523 (Lord Denning); Regina v. Nott, 43 Crim. App. R. 8 (1960); Regina v. Bastian, [1958] 1 All E.R. 568. Contra, Regina v. Price, [1962] 3 All E.R. 957. The practice is now approved by the Criminal Procedure (Insanity) Act, 1964, 12 \& 13 Eliz. 2, c. 84, §6. 110 Republic v. Mandi s/o Ngoda, [1963] E. Afr. L.R. 153 (Tang.). 
be to produce the result that no party to the proceedings would be asking for a verdict of guilty, since either both prosecution and defense would concur in seeking a verdict of insanity, or the prosecution alone would seek it and the defense would ask for acquittal. ${ }^{111}$

This puristic view of the assigned roles in adversary proceedings seems to be both unnecessarily dogmatic and out of tune with the actual conditions of Africa. Of greater significance are the cases which have faced up to the problems of the shortage of expert psychiatric testimony, the unlikelihood that the defense would have access to a psychiatrist who is not a government-employed medical officer and the illiteracy and unsophistication of many defendants.

It has already been noted that in every jurisdiction, at least in a murder case, there is a good chance that psychiatric evidence will be made available. In many cases, if there is any reason to suspect that the accused is not mentally normal, he will be examined by a psychiatrist while in prison awaiting trial-but at the instance of the state rather than of the accused or his advisers. ${ }^{112}$ It seems to be established practice in most countries, following the English pattern, for the prosecution to provide the defense with a copy of the psychiatrist's or prison doctor's statement on the subject, and make him available as a witness to the defense if necessary. ${ }^{113}$ This is clearly an essential practice to insure fairness where the majority, if not all, of the medical practitioners are government employees.

Whether the defendant in a capital case is legally represented depends upon the state of the legal profession, the practice of assigning counsel to indigent defendants and the nature of the court. There may not be an adequate number of lawyers to insure representation in all cases, the courts may not be in a position to assign counsel or-even in capital cases in some jurisdictions-the trial may be in a native court in which legal representation is not allowed. If, therefore, the uneducated defendant finds himself without representation, it is abundantly clear that he will not be able to make the best use of any expert testimony made available to him. If, as should then happen,

111 Although the verdict would be "guilty but insane," it has been held that this amounts not to a guilty verdict but to an acquittal. Felstead v. Rex, [1914] A.C. 534.

112 See, e.g., Northern Nigeria Capital Cases Procedure, Part A (1960). The procedure calls for the obtaining of information about antecedents ("with special reference to his mental condition") by the police, id. Rule 2 , and observation and report by a medical officer while the accused is in custody awaiting trial. Id. Rules 5-11. If the accused is detained in a town which has no medical officer, he must be transferred to one which has. Id. Rule 12. In Kenya, in addition to other investigatory procedures, the magistrate must automatically inquire of the local mental hospital whether an accused has any record there at the time of committing him for trial on a capital charge. Circular to Magistrates, [1937] 2 Kenya L.R. 130.

113 Regina v. Emi, [1957] Rhod. \& Nyas. L.R. 201 (Nyas.) ; Nyinge s/o Suwatu v. Regina, [1959] E. Afr. L.R. 974 (Kenya). 
the court undertakes to guide him in presenting his defense, a number of alternative solutions are possible.

It could be held, as in South Africa, that the prosecution should produce the evidence of insanity and ask for a verdict based on it, even though the defendant objects. ${ }^{114}$ Kenya cases suggest that that country is moving in the same direction, ${ }^{115}$ but it remains to be seen if the Tanganyika suggestion ${ }^{116}$ that the prosecution should not do this will have any impact in Kenya. Malawi has adopted a procedure which appears to be the most satisfactory. The strategic decisions are left in the hands of the court, which should explain to the accused the implications of raising an insanity defense and allow the evidence to be called only if he then indicates that he is willing to face the consequences of a possible successful defense. ${ }^{117}$

It is commonly accepted that when the burden of proof is on the defense, it can be satisfied by the production of evidence which establishes the probability that the defendant was suffering from mental disorder within the statutory formulation. ${ }^{118}$ The only formal exception is in the case of Liberia which, though a common law jurisdiction, has not inherited the English procedures following a period of colonial rule. Section 15 of its Penal Law provides that once it has been established that the accused has previously suffered from mental disorder, the burden of proving that he committed the offense during a lucid interval then passes to the prosecution. No decisions have been reported on the questions of the burden and standard of proof when (as posited in the last two paragraphs) the defense does not call the evidence of mental disorder. It would be paradoxical if just because the accused were undefended and the evidence were produced by the prosecution, his mental condition had to be established by the higher standard of proof normally applicable to the prosecution. There would seem to be no reason why the standard of proof should not be deemed attached to the issue, whichever side raises it; the defendant's

114 Rex v. Holliday, [1924] So. Afr. L.R., App. Div. 250.

115 Nyinge s/o. Suwatu v. Regina, [1959] E. Afr. L.R. 974 (Kenya) ; Muswi s/o Musele v. Regina, 23 Ct. App. E. Afr. 622 (Kenya 1956). The Kenya courts have lent support to their position here by taking the view in addition that the prosecution must establish the accused's unfitness to stand trial if it questions it. Kaplotwa s/o Tarino v. Regina, [1957] E. Afr. L.R. 553 (Kenya).

116 Republic v. Mandi s/o Ngoda, [1963] E. Afr. L.R. 153 (Tang.).

117 Regina v. Mandala, [1957] Rhod. \& Nyas. L.R. 251 (Nyas.) ; Regina v. Emi, [1957] Rhod. \& Nyas. L.R. 201 (Nyas.).

118 Rex v. Wangara, 10 Ct. App. W. Afr. 236 (Gold Coast 1944) ; Rex v. Mwose s/o Mwiba, 15 Ct. App. E. Afr. 161 (Kenya 1948); Rex v. Ashigifuwo, 12 Ct. App. W. Afr. 389 (Nig. 1948); Regina v. Yaro Biu, [1964] No. Nig. L.R. 45; Rex v. Kachinga, $13 \mathrm{Ct}$. App. E. Afr. 135 (Nyas. 1946); Rex v. Smit, [1950] 4 So. Afr. L.R. 165; Rex v. Sprighton, [1939] So. Rhod. I.R. 34; Republic v. Kiunga, [1963] E. Afr. L.R. 1 (Tang.); Rex v. Kabande s/o Kilugwe, 15 Ct. App. E. Afr. 135 (Uganda 1948). 
insanity is to be established and whoever establishes it should only have to establish its probability. ${ }^{119}$

\section{Evidence of Mental Disorder: the Nature of the Evidence}

With the shortage of psychiatric experts, it is hardly surprising that virtually all the courts have accepted that the defense of insanity can properly be established without expert evidence. Only in Liberia has the Supreme Court insisted that there can be no determination of insanity without medical evidence, ${ }^{120}$ although one is compelled to wonder how far this insistence is strictly followed in the absence of extensive medical facilities.

Elsewhere, when medical evidence is not available, the courts or juries have to rely on the inferences they can draw from the surrounding circumstances and the proved acts or admitted states of mind of the accused. The inferences will be directed toward establishing the two separate aspects of the defense: the existence of the mental disorder (however it may be legislatively described) and the accused's knowledge, capacity to control or whatever exempting feature may be specified.

The sophistication of courts faced with a claim of mental illness has generally grown since the day when a trial judge could be reported as saying that he believed after observing the prisoner in court that he was not a mentally normal person. ${ }^{121}$ Demeanor at the trial is now given little weight except to give visual confirmation to other evidence of disorder. ${ }^{122}$ Yet there is still to be found the judge who confesses that

in the absence of any evidence of treatment between the offense and the trial when it is alleged that the accused was insane when the offense was committed, one feels bound to look for some explanation of the fact that at the trial the accused is sufficiently sane to understand the nature of the proceedings ....123

119 The mental disorder bringing a woman within the offense of infanticide is deemed to give rise to a different situation from the straightfoward insanity defense. The burden of proving normality therefore rests on the prosecution and a reasonable doubt that the woman is abnormal will be sufficient to establish the defense. Namayaja v. Regina, $20 \mathrm{Ct}$. App. E. Afr. 204 (Uganda 1953). But query.

120 Carew v. Jessenah, 13 Liber. L.R. 168 (1958); Scott v. Liberia, 1 Liber. L.R. 430 (1904).

121 See Rex v. Anuku, 6 Ct. App. W. Afr. 91 (Nig. 1940).

122 Rex v. Ashigifuwo, 12 Ct. App. W. Afr. 389 (Nig. 1948) ; Regina v. Tembo, [i961] Rhod. \& Nyas. L.R. 858 (No. Rhod.). The accused in Ashigifuwo said he knew nothing about the charge or the offense; at times his answers were reasonable, at other times they were not; throughout he was listless and apathetic.

123 Regina v. Mandala, [1957] Rhod. \& Nyas. L.R. 251 (Nyas.). 
Fortunately, the variable nature of mental illnesses and their frequent episodic characteristics appear to be familiar conceptions in the minds of most judges. ${ }^{124}$

The crucial feature here is that the courts, so often relying on inference without medical help in assessing the significance of the inference, are in effect deciding for themselves the symptomatology of mental illness. That they approach this task carefully is beyond question; the accuracy of their diagnosis is another matter.

In their favor on both of these points is the fact that the courts have generally looked not at particular acts or aspects of the accused's life but rather at the totality of his situation. Diagnosis is not normally to be made on the strength of one or two aberrant actions but on the basis of an appreciation of as wide a range of factors as possible. If an accused has had pains in his head since childhood, frequently visited native doctors for this reason and taken their medicine, ${ }^{125}$ laughed maniacally, thrown his food away, gone out half dressed and babbled meaninglessly to his relatives, a court may naturally feel that he was not entirely normal. ${ }^{126}$ Even a less bizarre history could justifiably lead to the same conclusion.

The difficulties that the courts have got themselves into through lack of expertise appear to be twofold. First, in examining a broad range of factors which they feel may have causative significance in mental illness, they have at times been too uncritical; second, and more important, they have laid down legal propositions that certain symptoms are not to be given weight. They have, for example, accepted evidence of mental instability and behavior disorder in an accused's relatives without any consideration of whether the type of disorder from which he is suffering is transmissible. ${ }^{127}$ In other cases, of course, little critical ability may have been needed. Evidence of delusions, for many years in the nineteenth century considered essential to the existence of mental illness, ${ }^{128}$ will almost always lead to a finding

124 See, e.g., Regina v. Grumah, [1959] Ghana L.R. 307.

125 Rex v. Ashigifuwo, 12 Ct. App. W. Afr. 389 (Nig. 1948) ("not expert evidence of insanity but it is evidence of some abnormality of conduct"). Cf. Regina v. Yeboah, [1959] Ghana L.R. 434; Regina v. Grumah, supra note 124; Sudan Gov't v. Dafaala, [1961] Sudan L.J.R. 32.

126 These were the characteristics adduced in evidence in Rex v. Inyang, $12 \mathrm{Ct}$. App. W. Afr. 5 (Nig. 1946).

127 Ibid. This kind of evidence appears to have been given little weight in England. See Rex v. Smith, 5 Crim. App. R. 123 (1910); PItT-Lewis, Smith \& Hawke, The INSANe and the LaW 34, 232 (1895).

128 All the questions framed in the M'Naghten case were, of course, expressed in terms of total and partial delusions. For nineteenth century authorities which treated delusions as sine qua non, see Regina v. Townley, [1863] F. \& F. 839 (Martin, B.) ; Regina v. Barton, 3 Cox Crim. Cas. 275 (1848) (Parke, B.). The early stress on delusions in Anglo-American psychiatry is emphasized in DAIN, Concepts of INSANITY IN THE·UNITED STATES, 1789-1865, 6 (1964). 
of disorder. An accused's description of paranoid beliefs-that strangers went to his house to steal his wife or commit adultery with her, ${ }^{129}$ surrounding him with guns, machetes and sticks and trying to kill him, ${ }^{130}$ or abusing him and calling him names, ${ }^{131}$ is testimony that the nonmedical mind can readily appreciate.

The findings of law which exclude or deny significance to facts capable of amounting to symptoms of mental illness, however, represent the less informed side of the nonmedical mind. The courts' treatment of belief in witchcraft and supernatural powers is a good illustration. Just as in other fields they have discounted such beliefs and refused to allow them to affect the issue of responsibility for crime although they may have crucially altered an accused's perception of what he was doing, ${ }^{132}$ so in this field they have generally disregarded them as factors associated with mental illness. ${ }^{133}$ Only one reported case can be found to have given weight to them; the trial judge in Regina v. Magata s/o Kachehakana, expressed the opinion

that an African living far away in the bush may become so obsessed with the idea that he is being bewitched that the balance of his mind may be disturbed to such an extent that it may be described as disease of the mind. ${ }^{\mathbf{1 3 4}}$

Magata had murdered his father, believing him to be Satan and to have bewitched Magata's family. One wife, two sons and some goats had died; another wife, the accused himself and his cow were sickall, the accused alleged, as a result of the deceased's activities. It is clear that this is a particularly delicate area in which the greatest care

120 Rex v. Inyang, 12 Ct. App. W. Afr. 5 (Nig. 1946).

130 Nyinge s/o Suwatu v. Regina, [1959] E. Afr. L.R. 974 (Kenya) ; Echem v. The Queen, 14 Ct. App. W. Afr. 158 (Nig. 1952); Sudan Gov't v. Dafaala, [1961] Sudan L.J.R. 32.

131 Sudan Gov't v. Ishag, [1958] Sudan L.J.R. 1.

132 For example, self-defense based on a supposed attack by witchcraft has commonly been rejected. Konkomba v. The Queen, $14 \mathrm{Ct}$. App. W. Afr. 236 (Gold Coast 1952); Gadam v. The Queen, 14 Ct. App. W. Afr. 442 (Nig. 1954) ; Attorney Gen. v. Jackson, [1957] Rhod. \& Nyas. 443 (Nyas.). Such a belief, however, has been taken into consideration in East Africa in determining whether provocation existed in law. See, e.g., Rex v. Akope, 14 Ct. App. E. Afr. 105 (Kenya 1947); Rex v. Kajuna s/o Mbake, 12 Ct. App. E. Afr. 104 (Tang. 1945) ; Rex v. Fabiano, $8 \mathrm{Ct}$. App. E. Afr. 96 (Üganda 1941). The accused's belief that he was killing a spirit and not a human being has been held to exculpate in some jurisdictions, e.g., Sudan Gov't v. Nur, [1959] Sudan L.J.R. 1, but not in others. E.g., Rex v. Mbombela, [1933] So. Afr. L.R., App. Div. 269. The authorities are critically reviewed in Seidman, Witch-Murder and Mens Rea: $A$ Problem of Society Under Radical Social Change, 28 MODERN L. REv. 46 (1963).

133 E.g., Muswi s/o Musele v. Regina, 23 Ct. App. E. Afr. 622 (Kenya 1956) ; The Queen v. Tabigen, 5 Fed. Sup. Ct. 8 (Nig. 1960) ; Rex v. Radebe, [1915] So. Afr. L.R., App. Div. 96; Rex v. Molehane, [1942] So. Afr. L.R., G.W.L.D. 64.

134 [1957] E. Afr. L.R. 330, 331 (Uganda). 
must be taken. Belief in the immediacy of supernatural activity is widespread and is not statistically abnormal. Modern psychiatric studies suggest, however, that morbid fear of bewitchment and its consequences is closely associated with acute anxiety states, either as a cause or as a manifestation of the conditions. ${ }^{135}$ Although differentiation of pathological from culturally normal beliefs in witchcraft and the supernatural may itself be exceedingly difficult even for the psychiatrist, ${ }^{136}$ it is unfortunate that the courts should put themseives in the position of flatly rejecting the beliefs without further inquiry.

Similarly, lack of apparent motive for committing a brutal murder has been stigmatized by some courts as an unreliable guide to mental disorder, though psychiatrically it may be considered of some importance. ${ }^{137}$ The Zambian court in Regina $v$. Tembo ${ }^{138}$ agreed that a savage, apparently motiveless killing could be consistent with mental illness but suggested that it might also show

the mere indulgence of a savage but reasoning instinct . . . a brutal but perfectly sane desire to cause bloodshed . . . a foolish and reckless, but still not insane craving for notoriety-and . . possibly one or more or several other rational and culpable states of mind.

One legal writer has cautioned, too, that when dealing with the mental condition of "persons who, for no apparent reason, run about making violent attacks upon everyone they meet," one should bear in mind "that cruelty is a natural human instinct." 139

In West Africa, the courts have taken a less rigid view. Although they have held that motiveless behavior cannot by itself be used to support a finding of insanity, it may nonetheless give secondary sup-

135 See, e.g., Fiedd, The Search for Security passim (1960); Lambo, The Role of Cultural Factors in Paranoid Psychosis Among the Yoruba Tribe, $101 \mathrm{~J}$. Ment. Sci. 239, 247 (1955). The Cornell-A ro Study found a high correlation between belief in supernatural forces and mental disorder. Their tabulation below relates beliefs to mental disorder along a scale on which $A$ indicates positive disorder and $D$ normality :

$\begin{array}{lcccc}\quad \text { Beliefs in } & A & B & C & D \\ \text { Witches } & 55 \% & 46 \% & 26 \% & 5 \% \\ \text { Juju } & 25 \% & 19 \% & 12 \% & 2 \% \\ \text { Supernatural forces } & 14 \% & 10 \% & 2 \% & 2 \% \\ \text { Spirits } & 38 \% & 12 \% & 11 \% & 2 \% \\ & \mathrm{~N}=56 & 48 & 92 & 66\end{array}$

Leighton, Lambo \& Others, Psychiatric Disorder Among the Yoruba 146-47 (1963).

136 E.g., Lambo, sippra note 135 , at 247.

137 See, e.g., Whitlock, Criminal Responsibility and Mental Illness 27-28 (1963).

138 Regina v. Tembo, [1961] Rhod. \& Nyas. L.R. 858 (No. Rhod.). (1963).

139 Gredhill, The Penal Codes of Northern Nigeria and the Sudan 92 
port to make evidence of another sort more convincing. ${ }^{140}$ It is therefore particularly easy to use this inference where the accused has committed offenses against near and beloved relatives ${ }^{141}$ or has simply behaved in a wild and uncontrolled manner. ${ }^{142}$ It is difficult to think of any other verdict than one of irresponsibility when, for example, a man wanders into a completely strange village, sets fire to a hut, stabs an old man who tries to put the fire out, attacks and kills another man with a spear and a knife, sets fire to two more huts and finally wounds at least two other men before he is overpowered. ${ }^{143}$

It is in these cases of running amok that the courts can most easily operate within the framework of the cognitive and control tests. They can infer with confidence from the accused's behavior-whether he actually tells them so or not-that he did not know what he was doing. It is where the disorder takes a less dramatic and frenetic form that the determination of his capacity for knowledge or control will be more troublesome. The accused's own description of his state of mind may or may not be helpful and may or may not be believed. And the facts from which inference can be drawn may be ambiguoussuch as the accused's running away from the crowd at the scene of the crime, washing the murder weapon and apologizing for his behavior ${ }^{144}$ or immediately admitting the murder and surrendering to the police "to be killed." 145 Clearly even such an apparently unambiguous set of circumstances as buying a knife and stabbing a man

140 Rex v. Ashigifuwo, 12 Ct. App. W. Afr. 389 (Nig. 1948) ; Rex v. Inyang, 12 Ct. App. W. Afr. 5 (Nig. 1946); Regina v. Yayiye, [1957] No. Nig. L.R. 207; Salako v. Attorney Gen., [1965] Nig. Monthly L.R. 107 (W. Nig.).

141 See, e.g., Regina v. Yeboah, [1959] Ghana L.R. 434 (mother); Muswi s/o Musele v. Regina, 23 Ct. App. E. Afr. 622 (Kenya 1956) (wife); Echem v. The Queen, $14 \mathrm{Ct}$. App. W. Afr. 158 (Nig. 1952) (friend); Rex v. Ashigifuwo, supra note 140 (woman "like a mother to him") ; Sudan Gov't v. Mohamed, [1961] Sudan L.J.R. 199 (husband) ; Regina v. Magata s/o Kachehakana, [1957] E. Afr. L.R. 330 (Üganda) (father). It must be remembered, however, that in Africa as elsewhere, even in the absence of mental disorder, murder is most likely to take place within the family group, however that may be defined. See African HoMICIDE AND SUICIDE ch. 9 (Bohannan ed. 1960).

142 See, e.g., Regina v. Moshie, [1959] Ghana I.R. 343; Regina v. Grumah, [1959] Ghana L.R. 307; Regina v. Yayiye, [1957] No. Nig. L.R. 207; Sudan Gov't v. Dafaala, [1961] Sudan L.J.R. 32.

143 Sudan Gov't v. Ishag, [1958] Sudan L.J.R. 1.

144 Echem v. The Queen, 14 Ct. App. W. Afr. 158 (Nig. 1952). Echem was clearly schizophrenic with paranoid delusions.

145 Nyinge s/o Suwatu v. Regina, [1959] E. Afr. L.R. 974 (Kenya). Nyinge was held to be outside the M'Naghten defense on the ground that his immediate surrender and confession to the police established that he knew, at the time he killed, that he was doing wrong. But see WHITLOCK, op. cit. supra note 137, at 87:

It is in the setting of flatness or incongruity of mood that a schizophrenic patient can be overcome by an irresistible impulse to kill. . . . [I]t is not unusual for such a crime to be followed by the minimum of attempt to cover up its traces, or the murderer may even go to the police to confess. 
against whom the accused has a grievance may take on a different complexion against a background of mental disorder. ${ }^{140}$

Expert evidence on this crucial issue of cognition or control at the time of the offense, where it is available, needs to be specific and detailed. The courts are unlikely to challenge any psychiatric assertion that an accused was suffering from a mental disorder at the time of the offense, though since there must be a finding of fact on this issue based on all the evidence they are entitled to do so. The divergence from medical opinion, if there is divergence at all, comes on the issue of cognition or control. The observations of the Chief Justice of Malawi indicate the basis for disagreement:

In most cases the best evidence is that of those witnesses who can speak to the accused's actions and demeanour at and immediately before and immediately after the incident in question, and the experts can really reach their opinions only by inference from those facts supported by their expert knowledge of the subject and a somewhat belated examination of the accused. It is no wonder, therefore, that juries sometimes think that they can form just as good an opinion from the evidence as can an expert who has never seen the accused until some time after the moment at which he is alleged to have been insane. ${ }^{147}$

Without wishing to disagree with the Chief Justice's appreciation of the attitude of juries (which one feels can justifiably be extended to include many judges), much will surely turn on the psychiatrist's "expert knowledge." It is this knowledge which allows the psychiatrist to make an educated retrospective assessment of the accused's mental condition and state of knowledge in the light of the psychiatric diagnosis. The court obviously should not accept as adequate proof a categorical statement about an accused's state of mind which is unsupported by facts and reasoning. ${ }^{148}$ Nonetheless, by insisting too possessively on their right (or the jury's right) to be the final arbiters of fact, the courts often run the risk of undermining the significance of psychiatric testimony, reducing "expert knowledge" to the status of simple opinion, and injecting their rational appreciation of events into an inherently irrational situation.

146 Sudan Gov't v. Sakhi, [1961] Sudan L.J.R. 110. The accused had twice been under treatment-once apparently suffering from a remarkable "illness of false pretence"-and was found on examination the day after the offense to be mentally disordered. The court would not accept that the psychiatric history per se was enough evidence on which to base the defense, and dismissed the medical testimony on the ground that it was uncorroborated and it was "known that most crimes are the result of temptation or impulses that are not resisted."

147 Regina v. Mandala, [1957] Rhod. \& Nyas. L.R. 251 (Nyas.).

148 Id. at 253; Sudan Gov't v. Sakhi, [1961] Sudan L.J.R. 110. 


\section{Conclusions}

The vital question is how far these tests and procedures are suited to Africa, given the conditions and facilities of Africa. They are not tests and procedures which were originally evolved in Africa, but ones which have been fashioned by colonial or independent legislatures in the image of foreign models. The Imperial government approved them not because they were culturally sensitive but because they both embodied familiar common law formulae and, if adopted on a broad enough basis, could offer colonial uniformity. African governments which have been criminal law-givers in the past few years have either copied the legislation of other African states (Bechuanaland-Zambia, 1963), adopted well-tried overseas models (Northern Nigeria-India, 1959) or simply re-enacted their own earlier provisions (Ghana, 18921960). And in Africa, as anywhere else, merely retaining a code provision without alteration has not necessarily signified acceptance, especially, as is true of Africa, when the new governments have been preoccupied with the basic tasks of national development and are content to leave their legal affairs in the hands of English or Englishtrained lawyers.

Are these provisions the right ones for African countries today? When one considers the state of community knowledge of mental illness, the nature of the indigenous forms of treatment and the general inadequacy of modern medical facilities, one is tempted to draw a parallel with Europe and the United States in the late eighteenth and early nineteenth centuries. The tests for the recognition of mental illness and the criteria of criminal responsibility which were adopted were culturally viable in those times and places, whatever we may feel today about their inadequacy. ${ }^{149}$ Perhaps it is possible, assuming the equation of modern Africa with Europe and the United States one hundred fifty years ago, to make use of the methodology developed then.

The suggestion must be firmly rejected. First, the argument can be made on the general grounds of scientific development and of international responsibility to assist in the spread of informed attitudes. We should no more think of reverting to a pre-psychiatric test of responsibility than we would of advocating a wholesale return to bloodletting, blistering and purging as measures of treatment. Although individual communities in Africa may be effectively isolated

149 I have relied for my information about the historical appreciation of mental illness on DAIN, op. cit. supra note 128 , and $\mathrm{K}$. JONES, LUNACY, LAW \& CoNSCIENCE, $1744-1845$ (1955). 
from the main currents of modern medical thought, the nations of which these communities form part are not. Their facilities may be poor, but they are not themselves wholly unaware of this; to suggest that they isolate themselves even further from scientific development would be neither ethical, humane nor politically feasible.

Secondly, there is certainly nothing to suggest that the variety of responsibility tests which were in common use in England or the United States before the formulation of the M'Naghten rules were capable of making a satisfactory distinction between the responsible and the irresponsible, or even between the dangerous and the nondangerous. From the "wild beast" test of the Arnold case ${ }^{150}$ through the various cognitive tests devised before the $M$ 'Naghten rules, ${ }^{151}$ the result was uniformly the same; only the manifestly disturbed were identified. Since at the time, however, medical opinion leaned heavily in the direction of recognizing delusion and hallucination, together with inappropriate behavior, as the principal symptoms of any mental disorder worthy of the name, the artificiality of the criminal responsibility tests simply insured the detention of the grossly disordered together with the grossly disordered who had been civilly committed..$^{152}$

Today, we therefore say that the tests based upon an oldfashioned pre-psychiatric view of mental illness are unsatisfactory. In the developed, scientific-age cultures of Europe and the United States we criticize the M'Naghten rules; they are based on a discredited view of the compartmentalization of the human mind; they focus unrealistically on the cognitive factor in mental disorder; they misleadingly rely on the concepts of delusion and partial and total insanity; they impede the giving of meaningful psychiatric testimony; they were devised under conditions of political pressure and probably narrowed the previously understood law; and they are workable only by reason of their regular breach. The result has been that the transatlantic jurisdictions have steadily moved away from the $M^{\prime} N a g h t e n$ position. Should Africa, torn between the nineteenth and the twentieth centuries in terms of its psychiatric facilities, do the same?

The preliminary answer is that some parts of Africa, as we have seen, have done so already. There is only one carbon copy of the

15016 How. St. Tr. 695 (1724).

151 The more important authorities are collected in K. JoNEs, op. cit. supra note 149, Appendix 1. It should be remembered, of course, that even apart from the "wild beast" of the Arnold case, the pre-M'Naghten tests were not uniformly cognitive. In Regina v. Oxford, 9 Car. \& P. 525, 173 Eng. Rep. 941 (1840), only three years before $M^{\prime}$ Naghten, Lord Denman, C.J., was directing a jury that "if some contributory disease was in truth the acting power within him which he could not resist, he would not be responsible."

152 See DAIN, op. cit. supra note 128, at 6. 
M'Naghten rules still in force and most of the significant developments are in the direction of expanding the responsibility tests to cover an accused's inability to control his behavior. Nonetheless, most of the jurisdictions retain impaired cognition and moral-legal judgment as essential criteria in their responsibility formulations.

It is generally true, as well, that in theory a defense based on the M'Naghten right-wrong test will be broader than it will be in England or the United States. This is the inevitable result of the diversity of the African communities and their differential contact with the formal laws and community standards of their nation. There is for any African who is not wholly integrated into a westernized urban environment some difficulty in appreciating the state of the laws enacted by a remote central government. With the diversity of African and westernized cultures and the constant conflict-modification process of social evolution, there will be similar difficulty in obtaining awareness of any single moral norm with which to accord one's behavior. When, as we have seen, it is these very facts of culture conflict and change which are at the root of much mental disorder in Africa, the conclusion follows that the M'Naghten defense will probably be more widely available in Africa than in any more homogeneous culture.

But there is a stronger argument in favor of retaining the present position: the difficulty involved in implementing a change. Psychiatric facilities-psychiatrists to examine, diagnose, treat and testify, hospitals to accommodate, drugs and equipment as diagnostic aids and for specialized therapies-are only irregularly available. Most African countries have some facilities, few have none, none have all. Without any question, all that exist are being put to maximal use. If the number of patients to be diagnosed and treated were to increase without any corresponding increase in the facilities, either diagnosis and treatment would become unprofessionally meager, or the system would break down. Neither is a palatable alternative. Yet either could be the consequence of broadening the present responsibility tests or of requiring pre-trial psychiatric examination on a wider footing.

If the present position does not change, on the other hand, an unsatisfactory system will be perpetuated. Most African countries, for example, have a mandatory death sentence for murder. The Roman-Dutch-based laws of southern Africa and the Indian-based code of Sudan recognize extenuating circumstances which may reduce the sentence to one of imprisonment. The mentally disordered murderer who does not fall within the responsibility exemption therefore either faces the death penalty with the prospect of possible execu- 
tive clemency, or hopes for a judicial exercise of discretion in his favor. ${ }^{153}$ But he may still be executed. ${ }^{154}$

Even conceding that he will not usually be executed, the result will be that the commuted sentence-or the judicial sentence in the case of a noncapital offense-will be served in prison. The consequences of this have already been examined; ${ }^{155}$ they are likely to be strictly nontherapeutic and the possibilities of transfer to some more therapeutic regime are not exactly well marked.

The practical realities of the situation are that no change will be made in African legislation and practices in this field in the foreseeable future. Legislatively and economically, the treatment of the mentally ill is a long way down the list of development priorities. Change must nonetheless be built into the fabric of social and legal attitudes so that the implementation of more progressive policies will be less painful when development has reached the stage of allowing it.

(1) Although legislation exists which makes possible pre-trial medical examination of criminal defendants, more can now be done to provide diagnostic and information-supplying services to the courts. They are particularly deficient at the present time as a result of the continent-wide shortage of trained probation officers. Most countries have had legal provision for probation services for decades but the slowness with which the provisions have been implemented has been uniformly discouraging. Too much weight cannot be attached to the valuable auxiliary task performed by probation officers in presenting relevant background information to the courts and in assisting with the work of screening defendants for mental illness. As more light is thrown upon personality characteristics and the circumstances in which offenses are committed, greater aid is given to the courts in deciding upon appropriate correctional measures.

(2) Something should be done to heighten the judges' awareness of psychiatric concepts, on a better-late-than-never basis. Although the supply of psychiatrists is slowly increasing, it will take many years

153 Regina v. Roberts, [1957] 4 So. Afr. L.R. 265; Rex v. Lloyd, [1941] So. Afr. L.R., C.P.D. 162; Rex v. Biyana, [1938] So. Afr. L.R., E.D.L. 310; Sudan Gov't v. Mohamed, [1961] Sudan L.J.R. 199.

154 See, e.g., State v. Harris, T.P.D. (So. Afr. 1965) (unreported). Harris was executed for causing the death of an elderly white woman by the explosion of $\mathrm{a}$ bomb in the concourse of the Johannesburg Railway Station. It was common ground between the psychiatrists on both sides that Harris was emotionally unstable and showed extensive personality immaturity (I am indebted to $\mathrm{Mr}$. D. Welsh of the University of Cape Town for this information). See also Sudan Gov't v. Wajo, [1961] Sudan L.J.R. 114: "The accused was not insane or weak minded, but he was emotionally unstable to an abnormal degree. In my view this should not be a reason for commutation of the death sentence."

155 See pp. 1140-42 supra. 
before expert assistance is available in every case in which it is desirable. In the meantime, the judges will continue to instruct themselves, assessors or juries, as the individual case may be, on what constitutes mental illness. At the moment, they have only an inadequate English legal education and their personal insights and sympathies to guide them. The answer may be a broader based education at the new African law schools, ${ }^{156}$ the interchange of information between psychiatrists and judges or even the straightforward supplying of information about the symptomatology of common mental illnesses. ${ }^{157}$ Amateur diagnosis is obviously dangerous, but amateur diagnosis that is sympathetic and partially informed is an improvement upon that which is neither. In due course, professional judgment involving clinical skill and experience would become available to supplant this makeshift "expertise."

(3) Were change possible, the responsibility tests should be remodeled. Quite apart from any criticism of unreality which may be directed against cognitive M'Naghten-type formulations, an effort could be made to simplify the issues. What amounted to mental illness would always have to be determined somewhat imperfectly by the individual parts of the judge-assessors-jury trio, and no doubt this would continue to lead to the identification of only the manifestly disturbed offenders. The level of awareness of the latter two parts of the trio ${ }^{158}$ might well be somewhat limited, but the hope is that with assistance and guidance from the judge, they will be able to function with more accuracy than at the present time.

If the basic postulate of mental illness, upon which the whole defense is to be based, can be described in the most general terms, the courts will be relieved of some of the embarrassment of trying to fit psychiatric categories into legislative language. A description such as "unsoundness of mind" would give sufficient flexibility for the courts to fit their various conceptions of mental illness into the statutory formula. There would inevitably be doubt about the inclusion of some psychiatric categories within this or any other description-

156 Although most of the criminal law teaching in the new law schools is sympathetic to inter-disciplinary understanding of these problems, there are to the best of my knowledge no courses presently given which explore the problems in legal and psychiatric depth.

157 GLEDHII, op. cit. supra note 139, at 91, gives a summary of some of the characteristics of major types of mental disorder, expressly on the basis of the difficulties in obtaining medical evidence. It is unfortunately not expressed in a very helpful form and is of too limited a nature to be of much practical value.

158 It is difficult to generalize about any community's awareness of mental illness. Some evidence suggests that it may be very highly developed. See, e.g., LEIGHToN, LAMBo \& OTHERs, op. cit. supra note 135, at 113-14; Gelfand, P sychiatric Disorders as Recognized by the Shona, in Magic, FAITH and Hraling 156 (Kiev ed. 1956). 
"psychopathy" or "sociopathy" in particular will probably defy classification (or even recognition) in the absence of psychiatric assistancebut simplification of the general terminology would make this no more difficult a task than under existing statutory formulae.

It is tempting to suggest that some guidelines might be laid down as matters of law to help the courts in their determination of mental illness. Probably too many factors weigh against it. The existing findings of law which dictate the weight to be given to particular symptoms are good illustrations of the dangerous tendency such rules have to exclude certain areas of testimony which could be significant. Judgment must be exercised by the trier of fact but prejudgment may do an injustice to the issue.

Moreover, simplification of the responsibility issue could be so arranged as to have the effect of reducing the number of issues upon which a psychiatrically unaided decision is needed. The determination of the issue whether mental illness exists cannot be avoided, for it is the sine qua non of the whole topic. But whether the morality of African peoples, their governments or their legal advisers would require the continuation of additional tests which call for the differentiation of different classes of the mentally ill, whether in terms of cognition or control, is another matter. Responsibility tests which called for exculpation simply on the showing of cause and effect between the illness and the offense would be neither inappropriate nor impossible to operate. $^{159}$ Indeed, the chances are that by reducing the issues in both number and intricacy, they may be more manageable.

(4) Lastly, it should not be impossible to make major improvements in correctional facilities without going so far as the wholesale revamping of the system of psychiatric institutional care. It is misleading to suggest, as one observer has, ${ }^{160}$ that the contribution of psychiatry to the solution of penal problems in Africa is necessarily measured by the presence or absence of psychiatric hospitals. Indeed, psychiatric hospitals of the conventional type have not adapted themselves easily to African conditions and doubt may genuinely be cast on how great a role they have to play in developed African penal systems.

Secure conditions of treatment are obviously going to remain a vital consideration in the case of some proportion of the mentally ill who find themselves caught up in the processes of the criminal law.

$159 \mathrm{I}$ am thinking here mainly of formulations in terms of the Durham test or the diminished responsibility test of the English Fomicide Act.

160 Clifford, The Evaluation and Methods Used for the Prevention and Treatment of Juvenile Delinquency in Africa South of the Sahara, 21 INT'x. Rev. CRmc. PoL. 17, 25 (1963). 
But it must be remembered that at the present time committal to African mental hospitals through these processes is not so much a function of the dangerousness of the patient-defendant's condition but of the lack of availability of other facilities. Were probation machinery to develop further, it would become feasible to make more regular use of the insertion of psychiatric treatment conditions into probation orders. In this way, the increasing availability of psychiatrists could be put to maximal use without at the same time calling for an impossible extension of institutional facilities.

Either by using the probation device, too, or by direct committal on a finding of irresponsibility, greater use could perhaps be made of other forms of minimum security treatment. Mental health work carried out in the context of Nigerian villages, for example, has demonstrated that a therapeutically organized community can give adequate care and minimize impairment and chronic illness. The cost has been found to be low and community attitudes favorable and helpful. ${ }^{101}$ And if by the extension of legal activity into these areas the emphasis commonly placed on the link between capital charges and mental treatment can be reduced, considerable impetus will be given to the orderly development of further cooperation between law and psychiatry. But for the time being, the spirit of Daniel M'Naghten lingers on. So too does that of the witch doctor. It will probably be many years before both are exorcised.

161 See note 7 supra. 